Covered in: Erih Plus; HeinOnline; CEEOL; RePEc; CrossRef; Google Scholar; KVK; WorldCat; ICI Journals Master List - Index Copernicus; EBSCO

2021, Volume 8, Issue 1, pages: 90-103 | https://doi.org/10.18662/elipa/8.1/152

\section{Some Reflections Regarding the Public Pension and The Number of Pensioners in Romania, in The Period 2010-2021}

\author{
Maria-Cristina BĂLĂNEASA ${ }^{1}$, \\ Cătălina DOGOTARI²
}

${ }^{1}$ Lecturer Ph.D. “Ştefan cel Mare"University of Suceava, Romania, Faculty of Law and Administrative Sciences

cristina.balaneasa@,fdsa.usv.ro

2 Bachelor's Graduate"Ştefan cel Mare" University of Suceava, Faculty of Law and Administrative Sciences, Suceava, Romania dogotaricatalina02@gmail.com

\begin{abstract}
The current importance of public pensions is given by the fact that this is the main form of support for inactive or unemployed people.Through this article we aim to review, in a brief way, the evolution and particularities of public pension.In particular, we want to analyze the evolution of the number of retirees in the public system, of the average pension but also of the service pensions during the years 2010-2021, in order to identify some directions for improving the public pension system.
\end{abstract}

Keywords: public pension, pensioners, old-age pension, early retirement, invalidity pension.

How to cite: Bălăneasa, M.-C., \& Dogotari, C. (2021). Some Reflections Regarding the Public Pension and The Number of Pensioners in Romania, in The Period 2010-2021. European Journal of Law and Public Administration, 8(1), 90-103. https://doi.org/10.18662/elipa/8.1/152 


\section{General information on public pension}

Pensions are the most important social insurance benefit provided in the public system.

State social insurance pensions are defined as "money rights granted to employees at the expiration of a certain period of activity and at reaching the age provided by law or in case of loss, total or mostly, ofwork capacity, as well as to the descendants of these people" (Ghimpu et al., 1978).

The public pension system in Romania has undergone for the first time a consistent reform through the first normative act after 1989, by Law no. 19/2000 regarding the public pension system (Romanian Parliament, 2000) , repealed by Law no. 263/2010 regarding the public pension system (Romanian Parliament, 2010), in force andtoday.Through these normative acts, the pension system was radically reformed.

The first normative act established the widening of the taxpayer base, the change of the pension calculation formula, the division of the obligation to pay the social insurance contribution between the employee and the employer, the increase of the contribution period and of the retirement ages (Beligrădeanu, 2000).

The second normative act, with application of approximately 11 years, underwent numerous modifications, including during the pandemic period, the last normative act being Law no.197 of July 16, 2021 (Romanian Parliament, 2021), which comes with additions regarding the reduction of retirement ages for old age.

Through the new normative act, the public pension system and the personnel from the former military systems were integrated : military personnel, soldiers and volunteer ranks, police and civil servants with special status from the penitentiary administration system, in the field of national defense, public order and security national (Ene \& Enache, 2012).

\section{Pension categories regulated by Law $263 / 2010$}

Law 263/2010 regulates the following categories of public pensions: old-age pension, early retirement pension, invalidity pension and survivor's pension (Romanian Parliament, 2010). 
The old-age pension applies to people who meet the conditions required by law at the time of retirement.A first condition would be age and the second is represented by the contribution stage.For men, the retirement age is 65 years and 63 years for women until 2030. The minimum contribution period is 15 years for both women and men.

The early retirement pension is due to persons who have completed the full contribution period, as well as to those who have exceeded the contribution period by up to 8 years.

The invalidity pension is specific to persons who have lost all or at least half of their working capacity, have contributed to the public pension system, but have not fulfilled the conditions for granting the old-age pension.

In accordance with Law no. 448/2006, on the protection and promotion of people with disabilities (Romanian Parliament, 2006), the persons who have completed a contribution period in disability conditions have the right to benefit from the reduction of the standard retirement ages, this being proved bycertificate.

The degrees of disability that result in the reduction of work capacity are divided into 3 categories, accordind to the Law 263/2010:

- first degree disability, is characterized by total loss of work capacity, by severe functional deficiency, by the inability of the disabled person to self-serve, thus requiring permanent supervision from another person;

- second degree disability, is characterized by maintaining the person's ability to self-serve, to direct and to orient themselves independently, thus the work capacity is significantly lost;

- third degree disability, is characterized by the possibility of the disabled person to perform a professional activity.

The survivor's pension is specific to the children and the surviving spouse, if the deceased was retired or met the conditions for obtaining the pension.Children under the age of 16 are entitled to a survivor's pension, those who are employed in a form of education up to the age of maximum 26 years.In the case of marriages of at least 15 years, the surviving spouse is entitled to a survivor's pension for the rest of his or her life at the standard retirement age. If the duration of the marriage is at least 10 years, the 
amount of the survivor's pension due to the surviving spouse shall be reduced by $0,5 \%$ per month (Ene \&Enache, 2012).

\section{Contemporary trends in changing the public pension system}

The government between 2020-2021 aimed to elaborate a new pension law with a fixed formula, based on statistical data on pension growth, respectively to favour small pensions, and while applying growth formulas, to recalculate all pensions. With regard to the public pension system, the Government had committed itself to voluntarily raising the retirement age through measures to encourage the population to remain in employment;equalization of the retirement age between genders but also the recalculation and verification of all pension files. The new pension law should come into force at the end of 2023, or in the context of the problems related to the governmental changes facing Romania, most likely this legislative proposal would not be able to be partially or totally fulfilled (Digi24, 2021).

\section{Micro-research on the number of pensioners, by categories and the amount of pensions in Romania in the period 2010 - March 2021}

The purpose of the micro-research is to analyze the evolution of the number of pensioners in the public system, of the average pension but also of the service pensions during the years 2010-2021 in order to identify some directions for improving the public pension system (National House of Public Pensions from Romania, Studies and Analysis Service, 2021).

In Figure 1 we present the statistics of pensioners in Romania, referring to all categories of public pensions for the years 2010-2021 (until March inclusive).We find that the total number of retirees in Romania, during the 12 years, has experienced an annual oscillation around the number of 4,500,000 retirees.In 2014, there is a sharp increase that brings the number of retirees to 5,196,073 retirees.In March 2021, the number of retirees decreased to 4,663,786 retirees, 553,000 less than in 2014.

The year 2020 saw the largest increase after 2014, registering 4,765,160 people. 


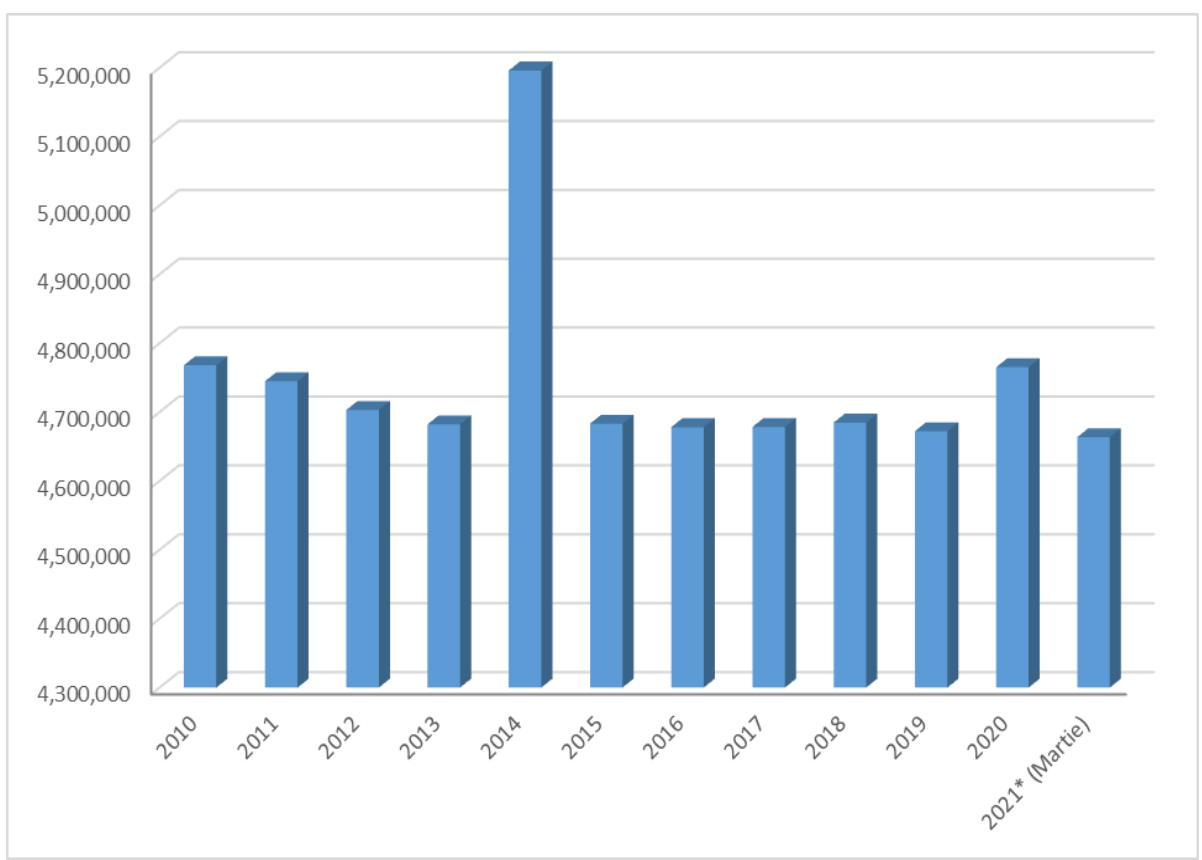

Fig. 1.Total number of pensioners in Romania, in the period 2010-2021 Souce: own processing according to the data provided by the National House of Public Pensions from Romania (2010-2021)

Figure 2 presents the evolution of pensions in Romania for all categories of public pensions. We notice that the number of pensioners for the age limit is in a slight but continuous increase from one year to another, so that in 2010 the number of pensioners was about 3,184,000, gradually reaching now over 3,650,000.

At the same time the number of people who can benefit from an invalidity pension is decreasing, therefore their number for 12 years has decreased by $50 \%$, for 2010 there were over 800,000 pensioners who are granted an invalidity pension, but inin March 2021 there were 430,000 beneficiaries.

Also, for 12 years the number of beneficiaries of the survivor's pension decreased, so that in 2010 there were over 560,000 retirees, and in 2021 their number was 100,000 less.

In the case of early and partially early pensions, the number of beneficiaries differs from year to year, so that the lowest number of persons receiving early pensions was registered in 2010 being 9,000, but the highest number was 23,000 in 2016 , so that currently this number is just 
over 14,000.The number of pensioners receiving the partial early retirement pension is also decreasing, starting with 2010 registering 12,000 pensioners, gradually this number decreased to 9000 .

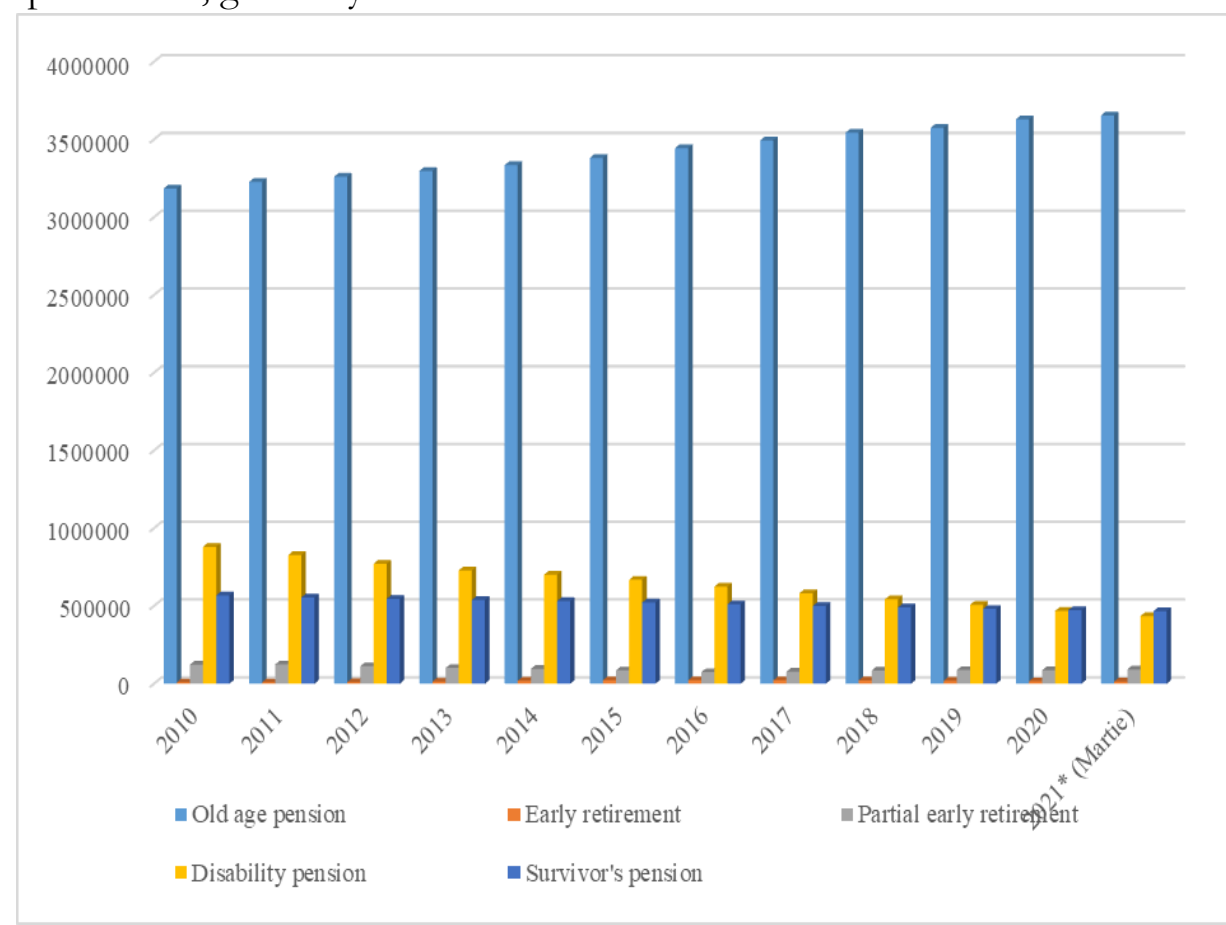

Fig. 2.Number of pensioners by pension categories in Romania in the period 2010March 2021

Source:own processing according to the data provided by the National House of Public Pensions from Romania (2010-2021)

From Figure 3 we note that in the case of the average pension for the age limit, this was in March 2021 of 1,797 lei. In the case of the disability pension, the average amount was 756 lei, and for the survivor's pension 829 lei, the average pension. Therefore, the highest average pensions are recorded in the case of early retirement, followed by the old-age pension. 
Some Reflections Regarding the Public Pension and The Number of Pensioners... Maria-Cristina BĂLĂNEASA \& Cătălina DOGOTARI

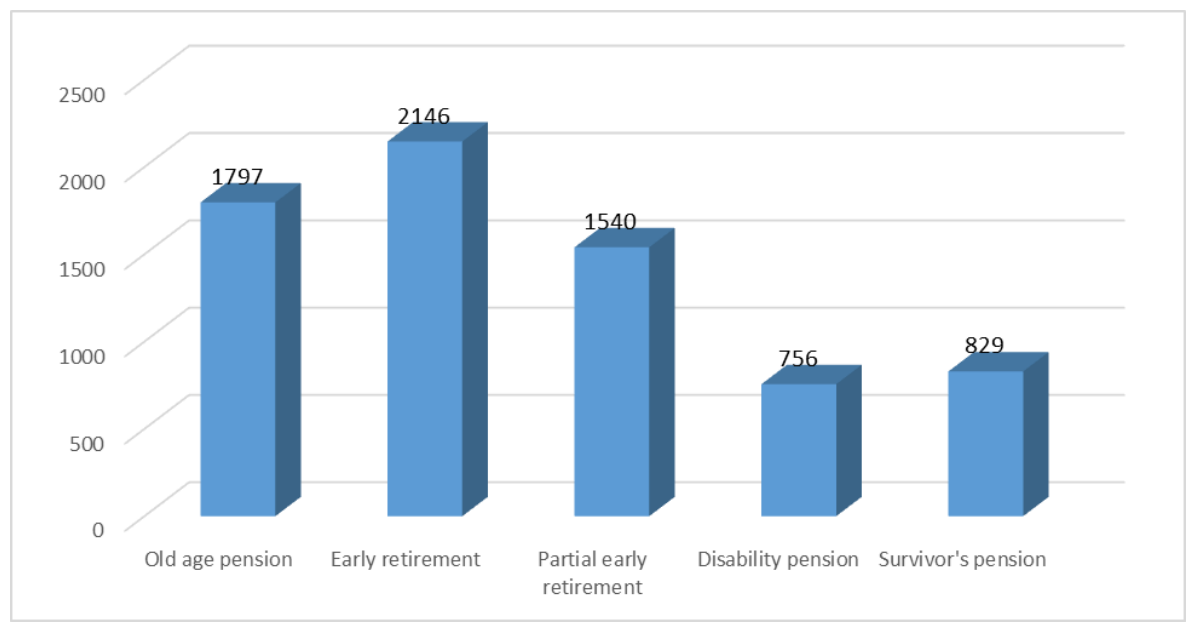

Fig. 3. The amount of the average pension in Romania for March 2021 Source:own processing according to the data provided by the National House of Public Pensions from Romania (2021)

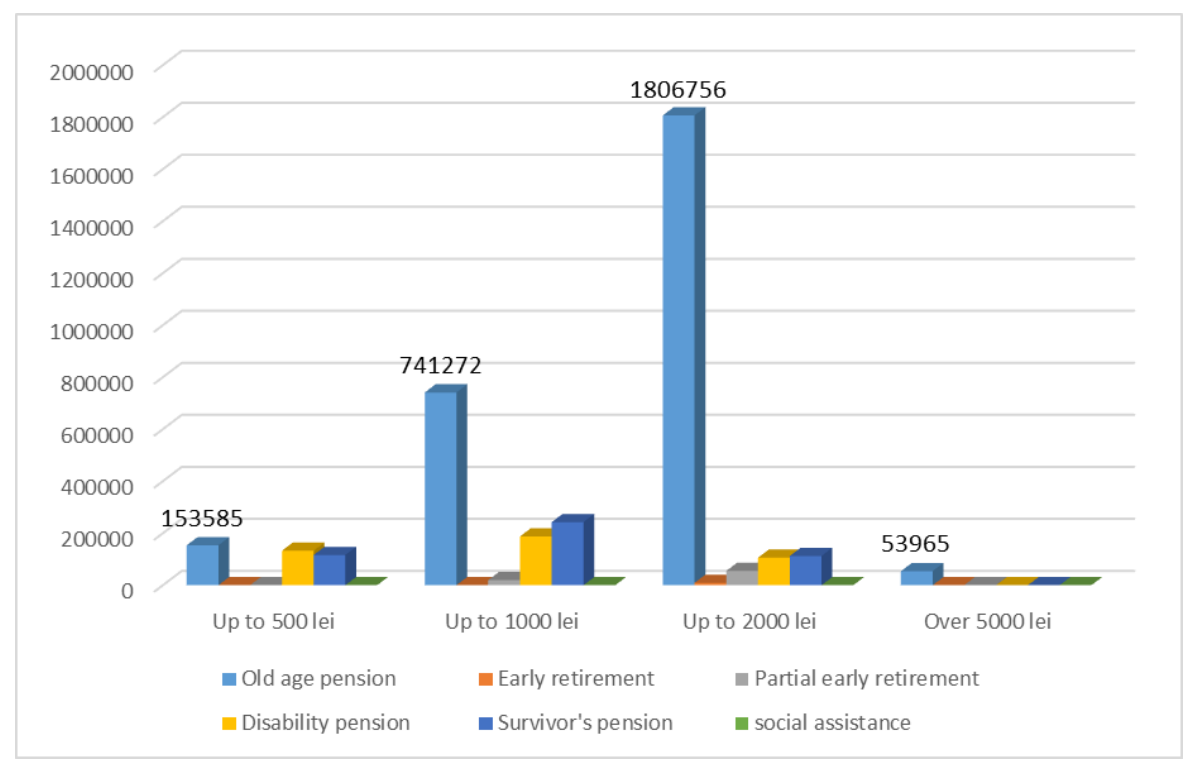

Fig. 4 The structure of the number of pensioners by pension levels in Romania in 2021

Source:own processing according to the data provided by the National House of Public Pensions from Romania (2021) 
We find that most pensioners $(1,806,756)$ receive a pension between 1000-2000 lei, only 53,000 thousand people receive an over 5000 lei pension.

Over 130,000 thousand people in Romania receive an invalidity pension in the amount of up to 500 lei, for over 180,000 people the state offers a monthly invalidity pension in the amount of 500 lei - 1000 lei.Only 186 Romanians benefit from the pension worth over 5,000 lei.

Most pensioners receiving a survivor's pension get between 5001000 lei.

The fewest Romanians benefit from social assistance, only 7 people benefiting from up to 1000 lei of social assistance.

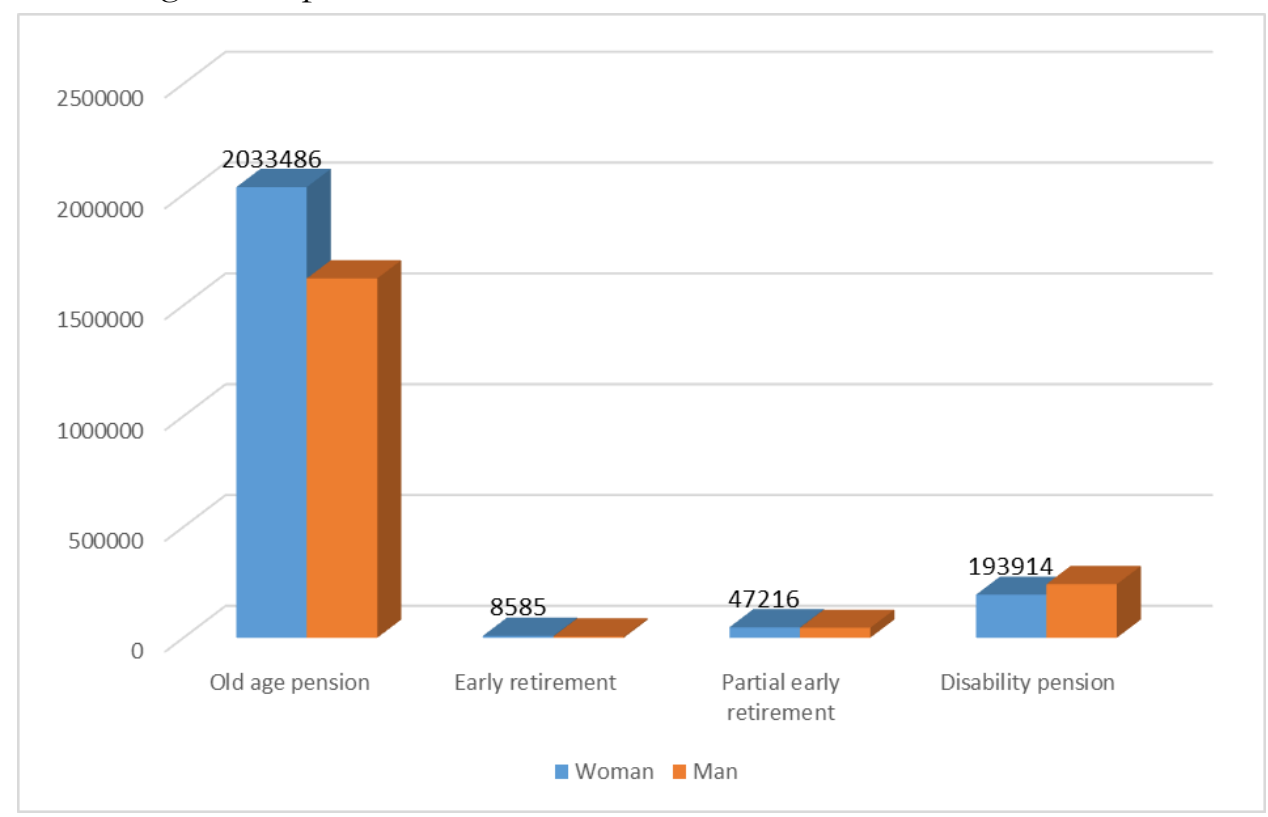

Fig. 5. Number of pensionaries by sex in March 2021

Source:own processing according to the data provided by the National House of Public Pensions from Romania (2021)

Figure 5 shows that most beneficiaries of the old-age pension are women $(2,033,486$ people), in the case of the disability pension the situation is reversed, men are more beneficiaries (241,417 people).

Regarding the pension point, starting with 2010 it was in a slight increase until 2020. If in 2010 the pension point was 732.2 lei, we find that 
since 2020 this value of the pension point has not increased, remaining also at the level of the amount of 1442 lei, as in 2020. (Figure 6).

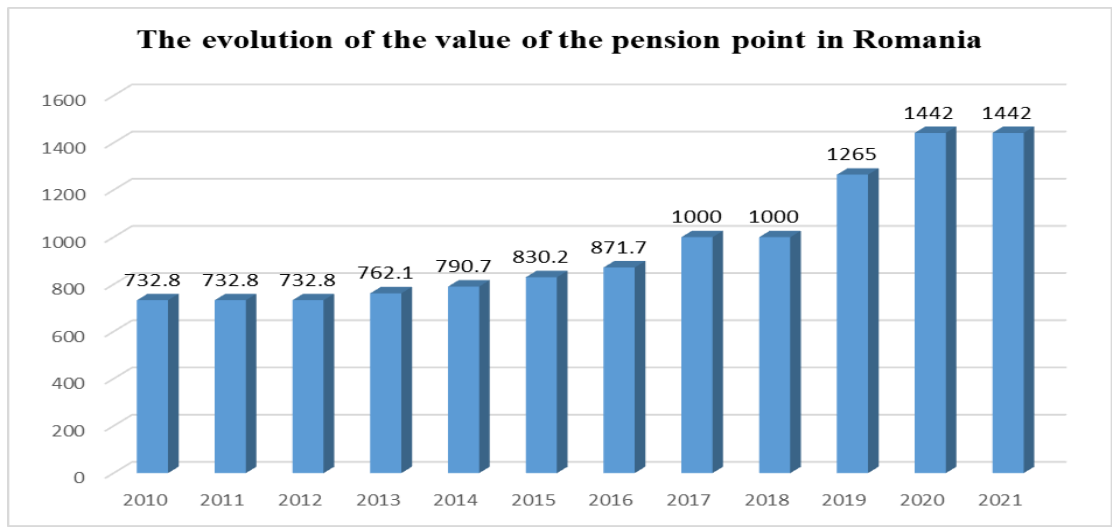

Fig. 6. The evolution of the value of the pension point in Romania(2010- March 2021)

Source:own processing according to the data provided by the National House of Public Pensions from Romania (2010-2021)

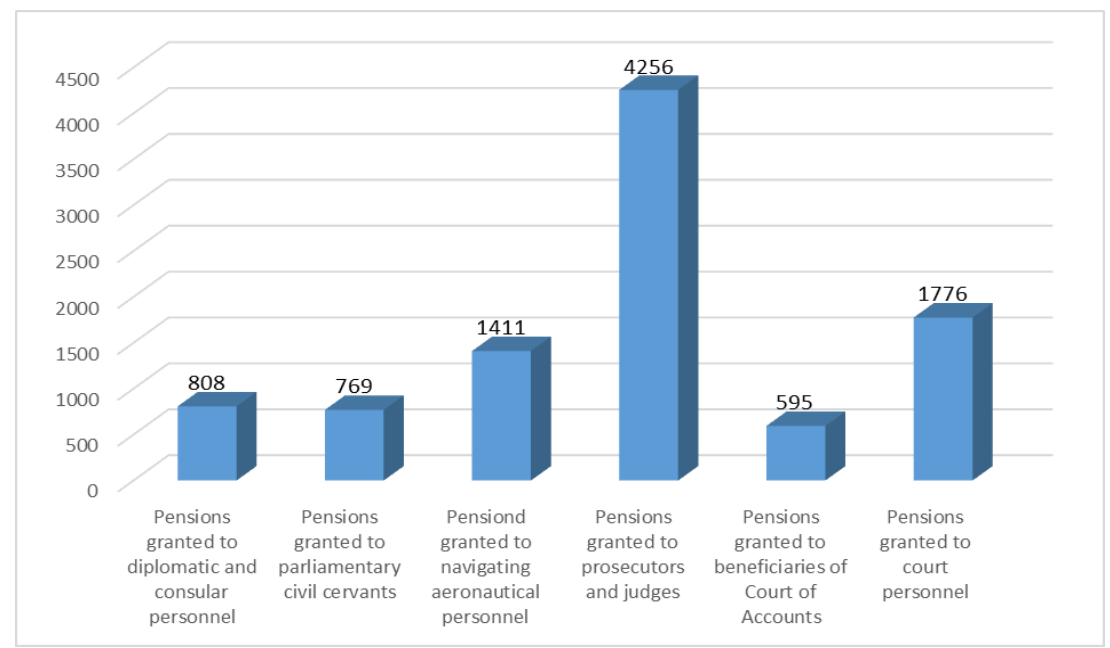

Fig. 7. Number of beneficiaries of public service pensions in March 2021 Source:own processing according to the data provided by the National House of Public Pensions from Romania (2021) 
Figure 7 reflects the situation of the beneficiaries of the public service pension in Romania.Out of a total of 9,615 beneficiaries, most beneficiaries are magistrates (4,256 people).

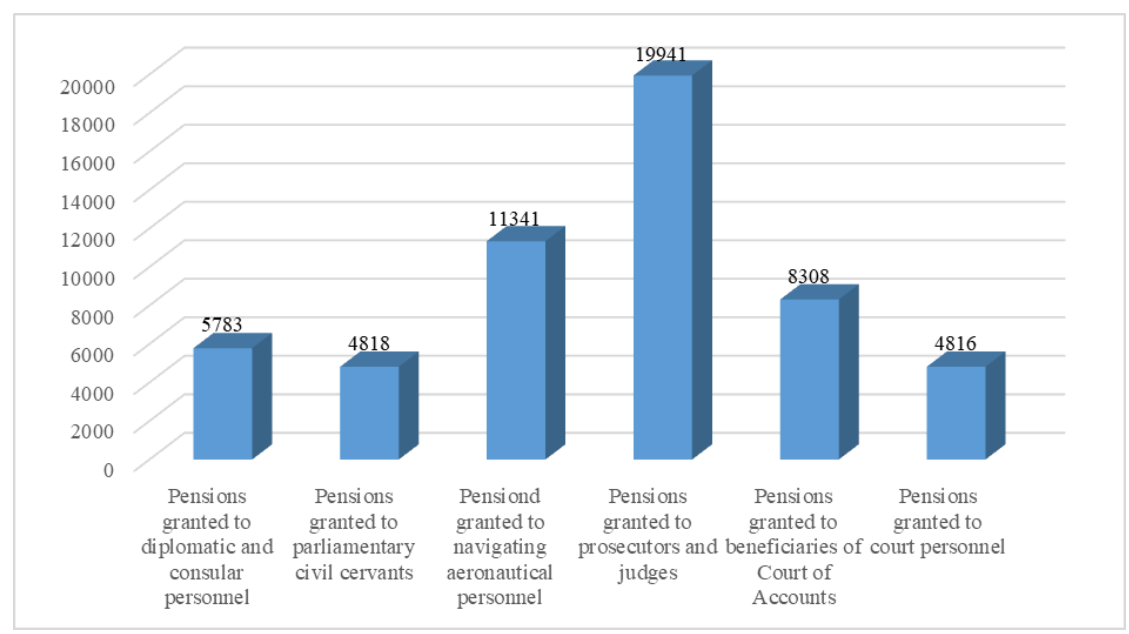

Fig. 8. The amount of the average service pension in March 2021

Source:own processing according to the data provided by the National House of

Public Pensions from Romania (2021)

Correlated with the number of beneficiaries of public service pensions, judges and prosecutors also benefit from the highest average pension - 19,941 lei (Figure. 8).

\section{Conclusions}

The whole world is facing a deep systemic crisis, especially with regard to pension systems. The citizens of Romania are waiting for changes and waiting for better times, in which the authorities should think more about meeting the needs of the retired population.Indeed, we can conclude that the legislation needs to be changed, if we look at the inequities in the amount of special pensions compared to those for employment or state pensions for old age.We must also take into account the future prospects regarding the relatively small number of active people who will contribute in the future to the state social insurance budget. 
Some Reflections Regarding the Public Pension and The Number of Pensioners... Maria-Cristina BĂLĂNEASA \& Cătălina DOGOTARI

\section{References}

Beligrădeanu, Ş. (2000). Impactul Legii nr 19/2000 privind sistemul public de pensii şi alte drepturi de asigurări sociale asupra legislației muncii [Impact of Law no. 19/2000 on the public pension system and other social security rights on labor legislation]. Revista Dreptul, 7.

Casa Naţională de Pensiile Publice, Serviciul proiecte, Studii şi Analize (2010). Statistică anuală 2010. Indicatorii de pensii de asigurări sociale de stat pentru anii 2010 [National House of Public Pensions from Romania, Studies and Analysis Service, State social insurance pension indicators for years 2010]. Casa Naţională de Pensiile Publice [National House of Public Pensions]. https://www.cnpp.ro/indicatori-statistici-piloni?p $\mathrm{p}$ id=101 INSTANCE svWpDmJy1qVq\&p p lifecycle $=0 \& p$ p stat

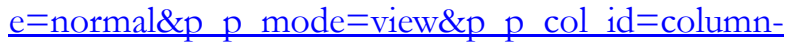
$1 \& p \_$_col_count $=2 \& p$ r_p 564233524 tag $=2010$

Casa Naţională de Pensiile Publice, Serviciul proiecte, Studii şi Analize (2011). Statistică anuală 2011. Indicatorii de pensii de asigurări sociale de stat pentru anii 2011 [National House of Public Pensions from Romania, Studies and Analysis Service, State social insurance pension indicators for years 2011]. Casa Naţională de Pensiile Publice [National House of Public Pensions]. https://www.cnpp.ro/indicatori-statistici-piloni? $p \_p \_i d=101$ INSTANCE svWpDmJy1qVq\&p_p_lifecycle $=0 \& p \_p \_s t a t$

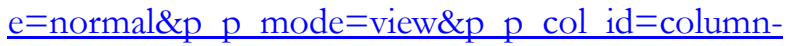
1\&p_p_col_count $=2 \& p \_r$ _p 564233524 tag $=2011$

Casa Naţională de Pensiile Publice, Serviciul proiecte, Studii şi Analize (2012). Statistică anuală 2012. Indicatorii de pensii de asigurări sociale de stat pentru anii 2012 [National House of Public Pensions from Romania, Studies and Analysis Service, State social insurance pension indicators for years 2012]. Casa Naţională de Pensiile Publice [National House of Public Pensions]. https://www.cnpp.ro/indicatori-statistici-piloni?p_p_id=101_INSTANCE_svWpDmJy1qVq\&p_p_lifecycle $=0 \& p \_p \_s t a t$

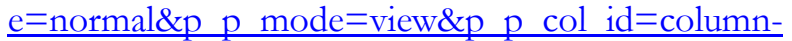
1\&p_p_col_count $=2 \& p \_r$ _p_564233524 tag $=2012$

Casa Naţională de Pensiile Publice, Serviciul proiecte, Studii şi Analize. (2013). Statistică anuală 2013. Indicatorii de pensii de asigurări sociale de stat pentru anii 2013 [National House of Public Pensions from Romania, Studies and Analysis Service, State social insurance pension indicators for years 2013]. Casa Naţională de Pensiile Publice [National House of Public Pensions]. https://www.cnpp.ro/indicatori-statistici-piloni?p $\mathrm{p}$ id=101 INSTANCE svWpDmJy1qVq\&p p lifecycle $=0 \& p$ p stat

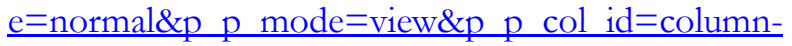
$1 \& p$ p col count $=2 \& p$ r p 564233524 tag $=2013$ 
Casa Naţională de Pensiile Publice, Serviciul proiecte, Studii şi Analize (2014). Statistică anuală 2014. Indicatorii de pensii de asigurări sociale de stat pentru anii 2014 [National House of Public Pensions from Romania, Studies and Analysis Service, State social insurance pension indicators for years 2014]. Casa Națională de Pensiile Publice [National House of Public Pensions]. https://www.cnpp.ro/indicatori-statistici-piloni? $\mathrm{p}$ id=101 INSTANCE svWpDmJy1qVq\&p p lifecycle=0\&p p stat e=normal\&p p mode $=$ view\&p p col id=column$1 \& p \_p \_c o l \_c o u n t=2 \& p \_r \_$_p 564233524 tag $=2014$

Casa Naţională de Pensiile Publice, Serviciul proiecte, Studii şi Analize. (2015) Statistică anuală 2015. Indicatorii de pensii de asigurări sociale de stat pentru anii 2015 [National House of Public Pensions from Romania, Studies and Analysis Service, State social insurance pension indicators for years 2015]. Casa Naţională de Pensiile Publice [National House of Public Pensions]. https://www.cnpp.ro/indicatori-statistici-piloni? p_p_id=101_INSTANCE_svWpDmJy1qVq\&p_p lifecycle=0\&p_p_stat

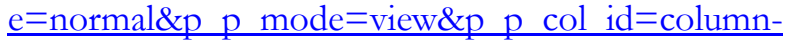
$1 \& p \_$_col_count $=2 \& p \_$r_p_564233524 tag $=2015$

Casa Națională de Pensiile Publice, Serviciul Studii şi Analize. (2016). Statistică anuală 2016. Indicatorii de pensii de asigurări sociale de stat pentru anii 2016 [National House of Public Pensions from Romania, Studies and Analysis Service, State social insurance pension indicators for years 2016]. Casa Naţională de Pensiile Publice [National House of Public Pensions]. https://www.cnpp.ro/indicatori-statistici-piloni? $\mathrm{p}$ id=101 INSTANCE svWpDmJy1qVq\&p p lifecycle=0\&p p stat $\underline{e}=$ normal\&p $\mathrm{p}$ mode $=$ view\&p $\mathrm{p}$ col $\mathrm{id}=$ column$1 \& p$ p col count $=2 \& p$ r p 564233524 tag $=2016$

Casa Națională de Pensiile Publice, Serviciul Studii şi Analize. (2017). Statistică anuală 2017. Indicatorii de pensii de asigurări sociale de stat pentru anii 2017 [National House of Public Pensions from Romania, Studies and Analysis Service, State social insurance pension indicators for years 2017]. Casa Naţională de Pensiile Publice [National House of Public Pensions]. https://www.cnpp.ro/indicatori-statistici-piloni? $\mathrm{p}$ id=101 INSTANCE svWpDmJy1qVq\&p p lifecycle=0\&p p stat

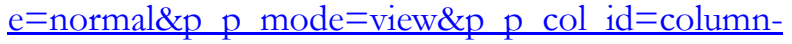
$1 \& p$ p col count $=2 \& p$ r p 564233524 tag $=2017$

Casa Națională de Pensiile Publice, Serviciul Studii şi Analize. (2018). Statistică anuală 2018. Indicatorii de pensii de asigurări sociale de stat pentru anii 2018 [National House of Public Pensions from Romania, Studies and Analysis Service, State social insurance pension indicators for years 2018]. Casa Naţională de Pensiile Publice [National House of Public Pensions]. https://www.cnpp.ro/indicatori-statistici-pilon- 
Some Reflections Regarding the Public Pension and The Number of Pensioners... Maria-Cristina BĂLĂNEASA \& Cătălina DOGOTARI

i?p_p_id=101_INSTANCE_svWpDmJy1qVq\&p_p_lifecycle $=0 \& p \_p \_s t a t$ $\mathrm{e}=$ normal\&p_p_mode $=$ view\&p_p_col $\mathrm{id}=$ column1 \&p_p_col_count $=2 \& p \_r$ _p 564233524 tag $=2018$

Casa Națională de Pensiile Publice, Serviciul Studii şi Analize. (2019). Statistică anuală 2019. Indicatorii de pensii de asigurări sociale de stat pentru anï 2019 [National House of Public Pensions from Romania, Studies and Analysis Service, State social insurance pension indicators for years 2019]. Casa Naţională de Pensiile Publice [National House of Public Pensions]. https://www.cnpp.ro/indicatori-statistici-piloni? $p \_p \_i d=101$ INSTANCE_svWpDmJy1qVq\&p_p_lifecycle $=0 \& p \_p \_s t a t$

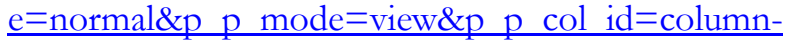
$1 \& p$ p col count $=2 \& p$ r p 564233524 tag $=2019$

Casa Națională de Pensiile Publice, Serviciul Studii şi Analize. (2020). Statistică anuală 2020. Indicatorii de pensii de asigurări sociale de stat pentru anii 2020 [National House of Public Pensions from Romania, Studies and Analysis Service, State social insurance pension indicators for years 2020]. Casa Naţională de Pensiile Publice [National House of Public Pensions]. https://www.cnpp.ro/indicatori-statistici-piloni?p $\mathrm{p}$ id=101 INSTANCE svWpDmJy1qVq\&p p lifecycle $=0 \& p$ p stat

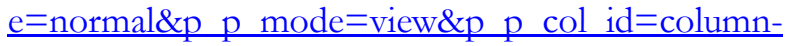
$1 \& p$ p col count $=2 \& p$ r p 564233524 tag $=2020$

Casa Națională de Pensiile Publice, Serviciul Studii şi Analize. (2021). Indicatorii de pensii de asigurări sociale de stat pentru luna martie 2021 [National House of Public Pensions from Romania, Studies and Analysis Service, State social insurance pension indicators for 2021, March]. Casa Națională de Pensiile Publice [National House of Public Pensions]. https://www.cnpp.ro/indicatori-statistici-piloni?p_p_id=101_INSTANCE_svWpDmJy1qVq\&p_p_lifecycle $=0 \& p \_p \_s t a t$ e=normal\&p p mode $=$ view\&p p col id=column$1 \& p$ p col count $=2 \& p$ r p 564233524 tag $=2021$

Digi24. (2021). Ce prevede reforma pensiïlor inclusă în PNRR: Creşterea voluntară a vârstei de pensionare, formula de calcul va fi schimbată [What the pension reform included in the PNRR provides: Voluntary increase of the retirement age, the calculation formula will be changed.]. Digi24.

https://www.digi24.ro/stiri/actualitate/politica/document-ce-prevedereforma-pensiilor-inclusa-in-pnrr-cresterea-voluntara-a-varstei-depensionare-formula-de-calcul-va-fi-schimbata-1549451

Ene, S.. , \& Enache, S. (2012). Pensii, Prestații sociale și Asigurări. Teorie şi practică [Pensions, Social Benefits and Insurance. Theory and practice]. Editura Monitorul Oficial R.A.

Ghimpu, S., Ştefănescu, I.T., Beligrădeanu, Ş., \& Mohanu, G. (1978). Dreptul muncii. Tratat, vol. I. [Labor law. Treaty, vol. I]. Editura Ştiințifică şi Enciclopedică. 
Romanian Parliament. (2000). Legea nr. 19 din 17 Martie privind sistemul public de pensii si alte drepturi de asigurări sociale [Law no. 19 of 17 March 2000 regarding the public pension system and other social security rights]. Monitorul Oficial, partea I, 140, 01 April 2000 [Official Gazette of Romania, Part I, no. 140 of April 01, 2000].

http://legislatie.just.ro/Public/DetaliiDocumentAfis/21690

Romanian Parliament. (2006). Legea nr.448/2006 din 6 decembrie 2006 privind protectia si promovarea drepturilor persoanelor cu bandicap [Law no. 448/2006 on the protection and promotion of people with disabilities]. Monitorul Oficial, partea I, 187, 19 Martie 2007 [Official Gazette of Romania, Part I, no. 187 of March 19, 2007].

http://legislatie.just.ro/Public/DetaliiDocument/77815

Romanian Parliament. (2010). Legea nr. 263 din 16 Decembrie privind sistemul unitar de pensii publice din România [Law no. 263 of 16 december 2010 regarding the on the unitary public pension system]. Monitorul Oficial, partea I, 852, 20 decembrie 2010 [Official Gazette of Romania, Part I, no. 852 of December 20, 2010]. http://legislatie.just.ro/Public/DetaliiDocument/124530

Romanian Parliament. (2021). Legea nr. 197 din 16 iulie 2021 pentru modificarea si completarea Legii nr. 263/2010 privind sistemul unitar de pensii publice [Law no. 197 of 16 July 2021 for amending and supplementing Law no. 263/2010]. Monitorul Oficial, partea I, 712, 19 iulie 2021 [Official Gazette of Romania, Part I, no. 712 of July 19, 2021]. http://legislatie.just.ro/Public/DetaliiDocumentAfis/244453 